\title{
O ENSINO DO LATIM NO COLÉGIO DO CARAÇA.
}

\author{
JOSE FERREIRA CARRATO \\ da Escola de Comunicaçōes Culturals da Universidade \\ de Săo Paulo.
}

Quando, em sua primeira viagem, o sábio naturalista A. de Saint-Hilaire arribou, em 1816, à Serra do Caráça, no centro da Capitania de Minas Gerais, e pôde contemplar, com olhos extasiados, o Hospício de Nossa Senhora Mãe dos Homens, engastado como uma gema no anfiteatro interno da montanha, suas primeiras palavras valeram como um vaticínio de bom profeta:

\footnotetext{
"Ao meu ver - disse êle - nenhum local será mais indicado d: que êste para fundar-se aqui uma casa de educação" (1).
}

Acontecia, porém, que naqueles dias o Caraça era apenas um eremitério, governado por um misterioso ancião, rodeado de alguns irmãos contemplativos, que desde 1774 ali estabelecera um santuário, sob a invocação de Nossa Senhora Mãe dos Homens, visitado desde então por levas devotas, em peregrinação. O ermitão respondia pelo nome de Irmão Lourenço de Nossa Senhora e entrara, em 1763, para o Ordem Terceira de São Francisco de Assis, no Arraial do Tijuco (2), onde então se dava ao negócio dos diamantes.

A lenda lhe acompanhara os passos e diziam, à bôca pequena, que, no século, antes de vir para as Minas, fôra um grande na Côrte de El-Rei D. José I. Achavam-lhe até um nome - que seria o verdadeiro - D. Carlos de Mendonça Távora (3), da ilustre estirpe dos Távoras, infamados e justiçados pelo govêrno implacável

(1). - Viagem pelas Provincias do Rio de Janeiro e Minas Gerais, Săo Paulo, Companhta Editôra Nacional (Braslliana), 1938, 2 volumes, t. I, p.. 196, infra.

(2) . - O requerimento do Irmळo Lourenço, com a sollcitaçáo de professar na Ordem Terceira da Penitência (de Săo Francisco), tem a data de 3 de outubro de 1763, e está no Arquivo da V. O. T. éa Penitência, em Diamantina (Minas).

(3). - A dúvida é se teria sido Lourenço o próprio D. Carios de Mendonça Távora. Porque êste nobre português de fato existiu, como o pudemos comprovar, pesquisando os batistérios do Arquivo dos Registros Paroquials (secçâo do Arquito Nacional da Tôrre do Tombo, de Lisboa), ao Livro B. 
do Ministro Sebastião José de Carvalho e Melo, o famoso Marquês de Pombal, indiciados que haviam sido de promoverem o atentado da noite de 3 de setembro de 1758 , que por um triz quase pusera fim à preciosa vida de Sua Majestade Fidelíssima. Outros, menos românticos, viam no estranho eremita apenas um negociante de diamantes, que viera do Tijuco, talvez um aventureiro como tantos outros que infestavam então as Minas Gerais, a amealhar o seu pecúlio, mas que, em dado momento,

"desenganado desde alguns anos do mundo, buscara o centro daquelas terras"

e, dispondo, por compra, de uma sesmaria de terras, ali fundara

"uma capela com o título de Nossa Senhora Mãe dos Homens e São Francisco das Chagas, com todos os seus pertences, ornamentos e imagens, alfaias e santuário de várias relíquias" (4),

que se tornara um ativo centro de romarias, rivalizando, mesmo, com o santuário do Senhor Bom Jesus de Matosinhos, de Congonhas do Campo, não mui longe dali.

Contudo, já valetudinário e entrado em anos, o Irmão Lourenço de Nossa Senhora fizera o seu testamento, assinado em 20 de março de 1806, doando sua fundação ao Príncipe Regente D. João, e nêle

\footnotetext{
"declarava que a sua vontade sempre fôra e era de que todos os referidos bens seus fôssem para estabelecimento e residência de Missionários, na forma do dito oferecimento a Sua Alteza Real, e não podendo conseguir-se para êsse fim, que em tal caso servisse para um Seminário de meninos, onde aprendessem as primeiras letras e mais artes, ciências e línguas, como Gramática, Filosofia Racional e Moral" (5).
}

dos Batizados de Souropires, fls. 36, onde fomos atinar com o seguinte assentamento: A margem: "Carlos $\mathrm{f.}$. de Paulo de Tavora edesuam.er D. Michaella" - "Carlos filho legitimo de Paulo de Tavora Coutinho e Sampayo, e de sua molher Dona Michaella; elle natural deste lugar de Souropires, ella natural da villa de Castello Bom Bispado de Lamego; nepto pela parte paterna de Antonio de Tavora Coutinho e de D. Bristis (sic) daCosta ambos deste dito lugar de Souropires; e pela parte materna nepto de Caetano de Sá natural de Alfaates e de sua molher Paula de Vasconcellos da dita Villa do Castello Bom tudo do Bispado de Lamego: nasceu emos Sinco dias do mez de Janeyro de mil esete Centos, e quarenta e outo annos, efoy baptizado solennemente por mim Abbade Encommendado abalxo assignado emos quinze dias do dito mez e era supra. Forão padrinhos José de Mendonça da dita Villa de Castello Bom; e como foy tambem por procuração que mefes o Reverendo Luis Carlos das Povcas Coutinho, Abbade de Avelaás da Ribeyra. E por ser verdade fis este assento, que assigney dias mes era ut supra. O Abb.e Encom.do Miguel Cardoso" (Livro B, fls. 36) .

(4). - Testamento do Irmão Lourenço de Nossa Senhora (Arquivo do Colégio do Caraça, C. D, ne 7), fls. 2 .

(5). - Idem, fls. 3 . 
Em 27 de outubro de 1819, o Irmão Lourenço morria e D. João VI entrava na posse de sua herança da Serra do Caraça.

Então, já diligenciara a vinda, para as missões entre os índios do Mato Grosso, dos padres lazaristas portuguêses, sediados na casa de Rilhafoles, em Lisboa. Chegados a Portugal desde os primeiros decênios de século XVIII, os filhos de São Vicente de Paulo gozavam de muito boa fama no Reino; devotados à catequese e à pregação junto das populações rurais, vinham os padres da Missão realizando profícuo apostolado entre as gentes mais humildes e abandonadas dos campos e das aldeias portuguêsas. Partindo, a 27 de setembro para o Brasil, chegaram, em dezembro de 1819, à Côrte do Rio de Janeiro, os Pes. Leandro Rebelo Peixoto e Castro e Antônio Ferreira Viçoso, enviados pelos seus superiores para as missões do Mato Grosso. E' de presumir, entretanto, que a política eclesiástica de D. João VI não era lá muito bem prevista, porque, tão logo chegados ao Rio os missionários lazaristas, receberam do Ministro do Reino, Tomás Antônio Vila Nova Portugal, a notícia de que houvera por bem Sua Majestade Fidelíssima atribuir-lhes outro mister: recebera El-Rei em legado um hospício e mais umas terras, na Serra do Caraça, em Minas Gerais, que ali possuíra um Irmão Lourenço de Nossa Senhora; pelos têrmos do legado a El-Rei o Irmão

\begin{abstract}
"lhe pedira a instituição de um Hospício de Missionários" naquele lugar; "considerando o quanto a Religião de Jesus Cristo que professava e a pura Moral que Êle ensina faz felizes os Povos e chama sôhre o Rei e os seus Vassalos as bênçãos do Céu, era também servido aprovar a mesma disposição testamentária (...) e determinar que no edifício e igreja sobredita ficasse estabelecido um Hospício para os Padres da Congregação da Missão de São Vicente de Paulo, a fim de que êstes não sòmente naquela igreja administrassem a palavra e socôrro espirituais, mas dali houvessem de sair em missões para os lugares da referida província de Minas Gerais e para as outras províncias aonde pudessem acudir e cs Ordinários do Lugar lhes pedissem: e para êsse efeito fazia doação da mesma Casa, Igreja, Terras e mais pertences da dita herança à Congregação da Missão; e determinava aos Padres Leandro Rebelo Peixoto e Castro e Antônio Ferreira Viçoso que fôssem dela tomar posse e estabelecer sua Casa Regular na conformidade dos seus Estatutos, e principiar a exercer as suas missões" (6).
\end{abstract}

O documento real de doação concluía assim:

(6). - Título de doaçáo do Caraça à Congregaçáo da Missão (Arquivo do Caraça, C. A. ne 12); Carta Régia de 31 de janeiro de 1820, in Collecção das Leis do Brazil (1820), Rio de Janelro, Imprensa Nacional, 1889, p. 19-20. 


\begin{abstract}
"No caso que os rendimentos das sobreditas terras não chegassem para a sustentação das missões, seriam soccrridos à custa da Real Fazenda" (7).
\end{abstract}

Eram os aludidos sacerdotes homens animosos e ardiam no zêlo da causa da fé, que desejavam ampliada ainda mais numa terra tão carecida de religião e de moral, como era então aquêle Brasil dos primórdios do século XIX. Por isso, não tiveram dúvidas em aceitar imediatamente a doação do legado real, aprestando-se desde logo para a partida. Após uma viagem acidentada pelo terrível carreiro de muares, que era o Caminho Real das Minas Gerais, ainda na estação das chuvas dos princípios do ano de 1820 , eis que os Pes. Leandro e Viçoso foram bater à porta do Hospício de Nossa Senhora Mãe dos Homens da Serra do Caraça, no dia 15 de abril daquele ano, recebidos pelos velhos escravos da casa, últimos remanescentes da fundação do Irmão Lourenço. No dia 29 do mesmo mês e ano, o Ouvidor da Comarca do Rio das Velhas, Dr. José Teixeira da Fonseca Vasconcelos, o futuro Visconde de Caeté, os metia na posse da herança e, já em junho, os dois missionários pregavam, na Freguesia de Catas Altas, a primeira missão lazarista que houve no Brasil.

O Pe . Leandro Rebelo Peixoto e Castro, Superior, deveria ser como bom minhoto - homem lesto e de boa diplomacia, porquanto, já em outubro daquele ano, regressando de viagem à Côrte, trazia na algibeira para o Caraça o título de "Casa Real" e mais uma dotação de cem mil réis anuais para as missões. Contudo, mais importante que o título e o auxílio de verba, era a decisão que tomara de iniciar, na Serra, imediatamente, um colégio para meninos: e, sem perda de tempo, já conduzia consigo, serra acima, os primeiros alunos, em número de quatro, todos da cidade do Rio de Janeiro.

O Colégio principia em dias do mês de novembro de 1820 , não se sabe qual. Abre-se a matrícula com os nomes dêsses primeiros alunos: Francisco de Paula, José Gularte, Manuel Maria de Lacerda e João Diniz. Meses depois, em agôsto de 1821, também está iniciado o noviciado, com a entrada do primeiro noviço da Congregação da Missão no Brasil, o Pe. João Moreira Garcez.

Caberá a êste Pe. João Moreira Garcez um papel preponderante na vida escolar do primitivo Colégio do Caraça. Ele será, afora os padres fundadores da casa, o primeiro mestre do Colégio, o primeiro professor de latim, que preleciona até sua morte, muitos anos depois

(7). - Carta Régia de 31.I.1820, in Colleç̧ăo das Leis, cit., p. 20. 
(1838). E com muito bom resultado, porque um ilustre visitante, que sobe ao Caraça em 1828, assim escreve sôbre êle:

\footnotetext{
"Apenas minha vinda foi anunciada ao Padre Garcez, êste teve a bondade de me vir falar. Notei nêle uma doçura extrema. Ele é o pai dos estudantes e tem um bom método de ensinar" (8).
}

Como o Superior, o Pe. Leandro, João Moreira Garcez estudara no tradicional Seminário Conciliar de Braga, fundado pelo célebre Arcebispo D. Frei Bartolomeu dos Mártires, logo após o Concílio de Trento, de que dá graciosa notícia o seu biógrafo Frei Luís de Sousa (9); depois de percalços diversos através de séculos, o velho Seminário fôra reavivado pelo zêlo de outro grande prelado, $D$. Frei Caetano Brandão, que trouxera para dirigi-lo dois lazaristas da Casa da Cruz, de Guimarães, ajudados por alguns professôres franceses, fugidos da Revolução (10). Ora, a linha informadora dos jovens levitas bracarenses ia entroncar, com as poucas modificações impostas pelas circunstâncias de tempo, pessoas e lugares, na grande matriz tradicional dos estudos clássicos eclesiástico-renascentistas, projetada desde o século XVI e expandida através dos séculos seguintes principalmente pela Companhia de Jesus.

O humanismo da Renascença é um movimento cultural que parte de uma atitude revisionista em relação a tudo que diga respeito à Idade Média. Atitude revisionista que abrange os campos político, religioso, econômico, social, filosófico, ético e estético. Não importa, como lembra Benedetto Croce, que a palavra "Renascimento" seja uma simples metáfora buscada no vocabulário religioso: a cultura nova, que se inicia nos meados do século XV e vai durar até os albores do século XVII, é visceralmente anti-tradicionalista e renovadora, às vêzes até revolucionária (como é o caso da Reforma e de certas tendências ético-artísticas), propondo como princípio de luta o ataque à ordem feudal medieval e como arma mais eficaz dessa luta o "retôrno" à arte, à literatura, à filosofia, ao modo de vida, à civilização enfim, dos gregos e romanos.

No campo específico do pensamento renascentista, além da rejeição em bloco do alegorismo, do simbolismo e do conceitualismo escolásticos, os humanistas do século XVI abominavam muito par-

(8). - Apud Pe. Pedro Sarneel, Guia Sentimental do Caraça, Belo Horizonte, Imprensa Oficial, 1953, p. 204-205.

(9). - Vida de D. Frei Bertolameu dos Martires, Lisboa, Tip. Rolandiana, 1857. 2 vols., t. I, p. 387 a 393.

(10). - Dr. Antônio Caetano do Amaral, Memórias para a História da Vida do Venerável Arcebispo de Braga $D$. Frei Caetano Brandão, Braga, Tip. dos Óffáos, 1867, 2a, ediçăo, 2 vols., t. II, p. 71 e 72 . 
ticularmente o latim medieval, que era o veículo linguístico natural do acervo cultural da Idade Média. Para chegar à cultura clássica, êles preconizavam o regresso ao latim do século de Augusto, principalmente o dos modelos ciceronianos, vergilianos e horacianos. $\mathrm{O}$ desprêzo ao latim vulgar foi se tornando tão grande, que alguns eruditos do tempo, tais como o Cardeal Bembo, Escalígero e Sadoleto, tapavam o nariz quando tinham de manusear a Vulgata de São Jerônimo ou, mesmo, quando compulsavam o Elogio da Loucura, de Erasmo de Roterdão... Foi à inspiração dessa mentalidade extreme de recondução aos moldes literários dos grandes mestres da latinidade clássica, que começaram a surgir, já na primeira metade do século $\mathrm{XVI}$, as escolas de latim, de grego e, mesmo, de hebraico: era o fogo de encôntro que se estabelecia contra as Universidades medievais, onde o latim vulgar dos textos e das preleções dominava, como instrumento universal de comunicação entre eruditos e semi-eruditos também. Essas escolas de línguas pleiteavam a volta pura e simples ao latim clássico, baseado no estudo e na interpretação de autores escolhidos, e o aprendizado do grego (língua pouco conhecida na Idade Média) e, às vêzes, do hebraico. A escola de latim chegara também a Braga, fundada pelo famoso mestre Clenardo, por mandado do Cardeal D. Henrique, e continuada depois pelo humanista Vazeo. Ao lado do Colégio de São Paulo, dos Jesuítas, e do Seminário Conciliar, iria constituir-se, na velha capital lusitana, talvez o centro mais importante de estudos latinos em Portugal, com os efeitos mais duradouros.

Quando os Jesuítas se estabelecem no Reino, sob D. João III, fundam, em Lisboa, o seu Colégio de Santo Antão. Ensinam ali, desde 1553, a quinhentos alunos seis mestres de latinidade. A procura do curso se acentua e, vinte anos depois, o Colégio é obrigado a aumentar suas classes ao dôbro. Portugal reflete bem o interêsse que vai por tôda a Europa pelos estudos das línguas clássicas. Aliás, desde princípios do século, partindo da Itália, o movimento atingira a Flandres (Louvain), a França (Sainte-Barbe, em Paris), a Espanha (Alcalá) e outros países. O latim clássico assumirá, em Portugal, tal prestígio que, nos tempos de Antônio Ferreira, já no terceiro quartel da centúria, desbancará o próprio vernáculo, a tal ponto que os humanistas Jerônimo Cardoso (poeta e gramático) e André de Resende acabarão por verberar a rudeza e a inexperiência do português, preferindo escrever suas obras em latim... Mas, Antônio Ferreira, eminente poeta e teatrólogo (autor da notável peça Castro), empenhará sua pena em defesa de um verdadeiro nacionalismo linguístico, não sòmente contra os partidários do latim, mas também 
contra as tendências castelhanizantes do tempo, acentuadas pelos imperativos políticos (11).

Para bem conhecermos a organização escolar e curricular dêsses primeiros estudos de latinidade, em Portugal, faz-se mister remontar às fontes donde êles provieram diretamente. Documento importante dessas fontes é o "Regulamento dos Estudos", aplicado ao Colégio da Guyenne, em Bordéus, pelo "principal" André de Gouveia, ilustre humanista lusitano, quando lá estagiou; êsse "Regulamento" foi publicado em 1583 por Élie Vinet, professor bordalês e amigo de Gouveia, e inclui todo o regime escolar então vigorante alị. A gramática era ensinada a dez classes, em que os alunos ascendiam das noções mais elementares às mais adiantadas; exames contínuos verificavam o progresso obtido nos estudos e promoviam os estudantes. Como no Colégio Santa Bárbara, de Paris, as classes eram comparadas às legiões romanas e seus componentes recebiam os respectivos títulos romanos, pelos números ordinais: desde os prima$n i$ (que correspondiam aos atuais últimos-anistas de colégio) até os decumani. Então, já o ambiente nas salas de aula era de ordem e limpeza; as crianças não mais se sentavam no chão, mas em escabelos cuidadosamente alinhados em anfiteatro, em volta do mestre; por três vêzes ao dia, o toque do sino trazia os alunos perante seus mestres. A aula pequena tinha lugar ao meio dia, depois do jantar: era a lição de sexta; as duas aulas de duas horas eram dadas de manhã, a partir das oito horas: era a lição de prima; à tarde, às três horas, era a lição de noa ou nona. A aula do meio dia (a pequena) destinava-se à exposição dos princípios, e as da manhã e da tarde à explicação dos professôres. Tudo era dado $\mathrm{em}$ doses homeopáticas. A partir da oitava classe, os alunos copiavam algumas linhas de um autor ou regra de um compêndio, que deveriam servir de texto para a lição, e eram obrigados a saber de cor o que copiavam. Um dêles recitava o primeiro trecho do passo transcrito, outro fazia a sua paráfrase em latim, um terceiro fazia a sua tradução literal na língua pátria, e assim por diante. O mestre incluía no devido lugar as observações que julgasse procedentes e passava, em seguida, a uma es. pécie de interrogatório, inexcedivelmente aproveitado, esmiuçando d:

\footnotetext{
(11). - Săo famosos os versos de sua Carta III (A Pêro de Andrade Caminha), em que exalta a língua pátria e verbera os que a desservem:

"Floresça, fale, cante, ouça-se e viva

A portuguêsa língua, e já onde fôr

Senhora vá de si, soberba e altiva.

Se téqui estêve baixa, e sem louvor,

Culpa é dos que a mal exercitaram:

Esquecimento nosso, e desamor".

Poemas Lusitanos, Lisboa, Sá da Costa Editôra, 1953, 2 vols., t. II, p. 48.
} 
tôdas as maneiras o pensamento do autor explicado, e perguntando como seria a expressão neste ou naquele caso. Os alunos aprendiam, assim, a propriedade dos têrmos, ao mesmo tempo que se familiarizavam com as regras da gramática e os recursos da sintaxe. Os processos medievais das competições ficaram apenas recordação: nas aulas de gramática, destinava-se apenas meia hora, após a aula da manhã, para os alunos, sem sair de seus lugares, se interrogarem uns aos outros, acêrca do que tinham ouvido. O tempo que restasse, depois dos trabalhos do dia, era empregado na composição de temas ou de versos latinos, sôbre matérias ditadas pelo mestre, e dêles levavam-se cópias para serem corrigidas em público. As aulas do sábado eram empregadas na recitação geral de tudo o que fôra aprendido durante a semana. As disputas dêsse dia demoravam mais tempo e tinham uma base diferente. Consistiam num verdadeiro exame, a que seis alunos de cada classe, cada um por sua vez, eram submetidos por seis outros alunos da classe superior. Assim os primani (os mais adiantados) julgavam os secundani, os secundani os tertiani, e daí por diante. Essa participação dos jovens no ensino só se dava a partir da $8^{\text {a }}$ classe. Os primani praticavam cursos de declamação, que se realizavam nos domingos, no salão maior, perante tôdas as classes reunidas. Era quando o grande teatro clássico dava os seus primeiros passos e os alunos que recitavam melhor eram convidados para representar peças teatrais, perante um público de pessoas especialmente convidadas. Completemos êste resumo com os programas de latim, da escola bordalesa. Os alunos iniciavam-se na leitura do idioma pelas Disticha Moralia, de Dionísio Catão, muito em voga no tempo, pelos Colóquios, de Maturino Cordier, humanista francês (que estêve com André de Gouveia em Coimbra, em 1547), e por Cícero e Terêncio. Estes dois últimos autores eram a base das leituras até o fim do curso, acrescentando-se-lhe, a partir da 5a classe, a poesia de Ovídio, e, a partir da $2^{\mathrm{a}}$, outros poetas latinos - Lucano, Vergílio, Pérsio, Juvenal e Horácio. Era também nas duas últimas classes que eram lidos os historiadores - Tito Lívio Patavino, Justino, Eutrópio, Pompônio Mela e Sêneca. Compunham-se versos latinos, a partir da $5^{\text {a }}$ classe, e se iniciava o estudo sistemático da Retórica, na $3^{a}$ (12). Como se vê, um programa quase completo de língua e literatura latinas, para uma época e cultura cujo lema era: Latine loqui et pie vivere.

(12) . - Resumo da organizaçáo e dos programas escolares do curso de gramática. no Colégio de Guyenne, feito por Jules Quicherat, in Histoire de Saint Barbe. Paris, 
Veremos que a Companhia de Jesus, que começou a operar naqueles dias dos meados do século, atenta, ao mesmo tempo, às prescrições de Santo Inácio de Loiola e às necessidades do momento, iria perfilhar, em boa parte, as notáveis experiências do Colégio de Guyenne e de Paris. Primeiro, porque das disputas entre o grupo bordalês que Gouveia levara a Coimbra (Santa Cruz) e os "parisienses" da Universidade portuguêsa adviera um salutar ecletismo pedagógico, que os Jesuítas aproveitaram bem, adaptando-lhes as tendências, muito boa achega para a futura consubstanciação do Ratio Studiorum (13), vindo a lume nos fins do século (1599); e depois, porque os currículos das disciplinas humanísticas propostos pela Schola Aquitannica convinham aos próprios intentos de Santo Inácio, que, nas Constitutiones de sua Companhia, preconizava corajosamente, contra a opinião de alguns tímidos pedagogos de sua Ordem, a inclusão de tôdas as disciplinas humanísticas. Ele próprio era um filho do seu século. Tôda a carreira dos estudos jesuíticos divide-se, assim, em três cursos parciais, distintos, mas uns articulados aos outros, desde que os inferiores irão preparando o caminho aos mais adiantados: o curso de letras ou línguas, o de filosofia ou de artes, e o curso de teologia. O curso de letras prepara para o curso de filosofia, e êste ao de teologia, o mais importante de todos, a que se darão com particular empenho os filhos de Inácio, visando as suas finalidades religiosas (14).

O curso de letras inclui o estudo das línguas latina, grega, hebraica, e outras que sejam úteis para a catequese e o apostolado (Anchieta, no Brasil quinhentista, se fará perito na língua geral da

(13) . - O Ratio studiorum é um repositório de normas e regras, mandado compor pelo Superfor Geral dos Jesuítas, Cláudio Aquaviva, em 1599, para reger o ensino e seu pessoal; no campo curricular, apresenta os estudos em superiores (Sagrada Escritura, hebraico, teologia escolástica, casos de consclência, filosofia, filosofia moral e matemática; e inferiores (estudos literários sôbre latim, grego, gramática). As regras disciplinam assuntos relacionados a govêrno dos colégios, formaçäo de professôres, vigilância doutrinária, métodos, subsidios didáticos, férlas, etc. O Ratio Studiorum resultou de uma verdadeira codificaçáo de princíplos fundamentais, metodológicos e pedagógicos, que se foram reunindo e que Aquaviva acabou por publicar. Os príncípios metodológicos constam da adoçăo dos seguintes métodos: o parisiense, de divisano de classes, de programas fixos, de exercícios e prêmios emulativos, e da guia do mestre ao aluno; o escolástico, com adaptação para as ciências eclestásticas. Os princíplos pedagógicos visam conseguir um desenvolvimento harmonioso da educação intelectual e moral, pela açáo da religiåo, motivo pelo qual a teologia é colocada no alto do currículo escolar, como a rainha das clências.

(14). - "Cum scopus - escreve Santo Ináclo, no proômío da Parte IV, das suas Constitutiones - ad quem Societas recta tendit, sit suas ac proximorum animas ad finem ultimum consequendum, ad quem creatae fuerunt, juvare". 
terra e escreverá para os seus curumins, assim como para os mestres inacianos, a primeira gramática dessa língua). Porém, no Ratio Studiorum, tôda a constelação das línguas gira em tôrno do latim. Em todo o curso literário, ensina-se, aprende-se e se aperfeiçoa o latim. Cada escola poderia ter as suas peculiaridades de trabalho escolar, mas

\footnotetext{
"quem tinha a primazia - escreve o Pe. Francisco Rodrigues, S. J., em seu livro A Formação Intelectual do Jesuita - quem regulava o andamento das classes e dava unidade à multidão dos labôres escolásticos e à variedade dos estudos, era a majestosa língua do Lácio. Com o latim se ensinava o grego, a língua pátria, a história e quanto compreendia o vastíssimo nome da erudição; entender os autores clássicos, falar corretamente o latim, escrevê-lo com elegância e primor ciceroniano era o alvo principal (grifos nossos) a que se dirigia o empenho do mestre e os esforços do discípulo" (15).
}

Os livros de texto eram compostos em latim e a língua que se falava em classe era necessàriamente o latim, uma vez que os alunos o pudessem entender, adverte o Ratio (16). No princípio, os alunos se vão dando à tabuada das declinações e das flexões verbais e decorando pequenas frases, bem acessíveis, para que o ouvido vá se educando, "como as avezinhas que principiam a ensaiar seus gorgeios melodiosos" - segundo a bela imagem do Pe. Pedro Perpinhão, famoso mestre de Coimbra (17). Assim, "por imitação", vão aprendendo a falar latim. Esse sistema, sugerido pelo Pe. Pedro Perpinhão, parece ao citado Francisco Rodrigues uma verdadeira antecipação do método de Berlitz, tão prestigioso desde o século passado (18).

O curso de letras iniciava-se pela gramática latina e avançava pelos três degraus de gramática ínfima, média e suprema. Da gramática passava-se à classe das humanidades, acabando-se os trabalhos na retórica. A célebre Arte de Gramática, do Pe. Manuel Âlvares - que Pombal, em sua luta contra o ensino jesuítico, faria substituir, depois dos acontecimentos de 1759, pela chamada Artinha Latina, do oratoriano Antônio Pereira de Figueiredo - compõe-se das três partes correspondentes aos graus de aproveitamento dos alunos: na classe infima, aprendem-se os rudimentos da Arte, com as regras mais simples da sintaxe, e, para as preleçôes, escolhem-se as

(15). - Francisco Rodrigues, S. J., A Formacāo Intelectual do Jesuita, Pôrto, Livraria Magalhăes \& Moniz, 1917, p. 42-3.

(16) . - Ap. Francisco Rodrigues, $O p$. cit., p. 43.

(17). - Ap. Franclsco Rodrigues, $O p$. cit., D. 43, infra.

(18). - Ibidem. 
cartas mais fáceis de Cícero; na classe média, estuda-se o quadro geral da gramática, visando-se a um conhecimento panorâmico deln, conhecimento suficiente, enquanto se explicam as cartas familiares de Cícero e excertos de Ovídio; finalmente, na classe suprema, procura-se ter um domínio completo dos preceitos e elegâncias da gramática latina, enquanto nos textos se vai a Cícero. E' curioso que, na escolha dos textos, os Jesuítas sejam bem mais sóbrios que os bordaleses de André de Gouveia. Os autores modernos, por exemplo, são sistemàticamente excluídos: Erasmo, João Luís Vives, Maturino Cordier, Tomás Mórus, etc.; são excluídos igualmente alguns autores antigos - que aparecem nos planos de Erasmo, Vives e, mesmo, de André de Gouveia - tais como Aristófanes, Plauto, Terêncio. E' que o conteúdo ideológico dêsses autores não condiz em absoluto com a doutrina da Contra-Reforma, de que os filhos de Santo Inácio são os melhores soldados, se bem que interessasse ao espírito muitas vêzes inovador da maioria dos homens do Renascimento.

"A escôlha dos Jesuítas - observa o historiador português Antônio José Saraiva - recai sôbre os textos cujo valor formal se sobreleva a qualquer outro" (19). Se "o que se tem em vista no Colégio Jesuítico - continua o mesmo Saraiva - é desenvolver nos alunos a capacidade dé expressão em estilo ciceroniano", a pedagogia inaciana iria interessar-se, principalmente, por uma "fruição puramente formal dos clássicos greco-latinos", o

que viria criar na mentalidade jesuítica um certo sentido apoético e não estritamente cristão, como pensa $D$. Miguel de Unamuno, em uma de suas obras (20). Eis aí, em suas linhas gerais, todo o sistema do ensino de letras - e, em especial, do latim - como aparece no Ratio Studiorum, e que vigorou até mesmo depois que a Companhia de Jesus foi banida de Portugal e do Brasil, não sòmente nos colégios jesuíticos, mas também nos seminários de formação do clero secular, onde até a Artinha do Pe. Manuel Álvares continuou a ser preferida, mais ou menos clandestinamente (21) .

Ora, é sabido que a expulsão da Companhia de Jesus do Reino de Portugal e de seus domínios, em junho de 1759, pouco ou nada modificou o estado do ensino do latim, nas casas religiosas. Aquela ostensiva proibição da Arte de Gramática, do Pe. Manuel Álvares,

(19). - História da Cultura em Portugal. Lisboa, Jornal do Fôro, 1955, 2v, t. II, p. 206.

(20). - La Agonia ael Cristianismo, Buenos A1res, Editorial Losada, 1938, todo o Cap. IX.

(21). - V. Laerte Ramos de Carvalho, As Reformas Pombalinas da Instruçáo Pública, São Paulo, Faculdade de Fllosofia, Clências e Letras da Universidade de São Paulo, 1952, p. 104. 
e a adoção obrigatória, nas escolas, do Nôvo Método de Gramática Latina, reduzida a Compêndio, do oratoriano Antônio Pereira, representam mais um acinte de natureza política do que pròpriamente uma posição inovadora de processos pedagógicos. Por outro lado, o espírito da obra substitutiva dos Oratorianos e de outras Ordens Religiosas portuguêsas não levava tanto a intenção de se opor ao estado de coisas até então vigente, mas o de superá-lo, pela aceitação e inclusão de muitos princípios e práticas adotados pelos tempos novos. Temos para nós, pois, que o Pe. João Moreira Garcez teria recebido em Braga, quando foi do Pôrto estudar no Seminário Conciliar, uma formação humanística não muito diferente daquela imposta pelo $R a$ tio a tôda estrutura portuguêsa do ensino de humanidades, desde dois séculos antes. No Relatório do Ouvidor Interino da Comarca de Sabará, Manuel Fernandes Correia Pinto, de 1828 - um dos documentos mais prestimosos do Arquivo do Caraça - assim é descrito o programa da "Aula de Gramática Latina", no qual, além da colaboração do Pe. Leandro Rebelo Peixoto e Castro, quase certamente o primeiro mestre de humanidades do Caraça, deve estar contida muito boa parte da experiência escolar bracarense do Pe. Garcez, atendidas as naturais circunstâncias locais:

"Aula de Gramática Latina, e esta como hé - não nos furtamos aqui à tentação de obedecer à saborosa ortografia do cimélio mais numeroza se divide em trez classas. $1^{9}$ anno em que só se explica, e argumenta os principics pelo Novo Methodo (do Pe. Antonio Pereira): $2^{\circ}$ anno, em que se tracta da versão e explicação da Syntaxe, mais diffusa do que o do $1^{Q}$ anno, e themas mais faceis da Lingua vulgar para Latim ensinando-se-lhes a reger em ambas as Linguas: $3^{\circ}$ anno se tracta propriamente do verço, e proza mais difficil, neste curso se applicão mais à compozição da Proza, e Distichos. Ensina-se-lhes a medição do verso Hexametro, Pentametro, e Lyrico de todas as qualidades, que uza Horatio nas suas Odes. Os livros classicos de que uzão são as 6 Selectas, Fabulas de Fedro, Oraçōes de Cicero, os Tristes de Ovidio, as Eneidas de Vergilio, todas as Odes de Horatio, excepto as impudicas (!), até a Arte Poética, que tem sido costume, depois de bem explicada mandar decorar em latim" (22).

Lá está, no mesmo documento, em seu Mapa $n^{0} 1$, na lista dos professôres, o nome do Pe. João Moreira Garcez, como "Diretor e Mestre da Gramatica Latina, Francesa e Geografia", que, na execução do programa acima citado, revela, nítida, a sua ascendência cultural de fundo jesuítico. Até mesmo nas defesas públicas de teses escolares, já desde 1828 promovidas no Caraça - ao nosso ver, as pri-

(22). - Arquivo do Caraça, Papéis avulsos. 
meiras que se realizam em Minas - estaria subjacente êsse legado, tanto jesuítico como vicentino, porquanto em Saint-Lazare (casa-mãe dos estudos lazaristas, em Paris), desde os tempos de São Vicente de Paulo, também se praticavam debates públicos sôbre questões escolares (23).

E' verdade que, antes do curso de latinidade do Colégio do $\mathrm{Ca}$ raça, já algumas escolas de humanidades latinas tinham existido e ainda existiam, em Minas Gerais. A alma mater das escolas mineiras é, incontestàvelmente, o Seminário de Nossa Senhora da Boa Morte, de Mariana, fundado pelo seu primeiro Bispo, o monge cisterciense D. Frei Manuel da Cruz, em 1750. Já na década seguinte ali pontificava, com fama por tôda a Capitania, o ex-jesuíta Pe. Pascoal Bernardino Lopes de Matos (24), insigne regente da cátedra de latim e retórica, mestre do Dr. Diogo Pereira Ribeiro de Vasconcelos, advogado e poeta da passagem do século XVIII e memorialista (25), de José Joaquim da Rocha, um dos patriarcas da Independência do" Brasil, e, talvez, de Frei José Mariano da Conceição Veloso, o grande naturalista, de Joaquim Veloso de Miranda, outro cientista eminente, do Pe. Antônio Rodrigues Dantas, o notável gramático e latinista, e do inspirado poeta e retórico Manuel Inácio da Silva Alvarenga. Um tal Gregório manteve no Inficionado (ou em Catas Altas, onde veio estudar brilhantemente o futuro poeta José Elói Otoni) um colégio de humanidades (26). Também em Guarapiranga (Piranga, hoje) o Pe. Manuel Pascoal teve o seu .Mas, o mais duradouro foi o Colégio dos Osórios, do Sumidouro, regido por tôda uma família de sacerdotes (irmãos, tios e sobrinhos),

\section{"dando muitas Capacidades e não equívocos Defensores da Re- ligiāo Católica, Apostólica, Romana" (27),}

dentre as quais destacamos o Cônego Francisco Pereira de Santa Apolônia, Presidente da Junta Governativa da Província de Minas

(23) - Pierre Coste, Monsieur Vincent, Paris, Desclée de Brouwer, 1931, 3 vols., t. II, p. 374 .

(24). - O primeiro grande mestre de latinidade, em Minas Gerais.

(25). - Autor de excelentes Memórias sobre a Capitania de Minas Gerais (in "Revista do Arquivo Público Mineiro", Ano VI, p. 757; allás, a Parte Inédita da Monografia fol publicada também naquela Revista (Ano I, $\mathbf{p}$. 443), sob o título Pessoas Ilustres da Capitania, onde aparece esta homenagem do Dr. Diogo Pereira Ribeiro de Vasconcelos ao Pe. Pascoal Bernardino Lopes de Matos, seu velho mestre; "Pascoal Bernardino Lopes de Matos, Bacharel Formado em Canones, e Presbitero Secular, he bem que viva nos escritos de hum discipulo, que fazendo justiça a todos a nao deve negar a hum Mestre, optimo Grammatico, e Latino, Escellente Retorico, e Orador". (Loc. cit., p. 452).

(26). - V. R, A. P. M., Ano VI, p. 497.

(27). - Ibidem. 
(o $1^{\text {o }}$ govêrno independente que teve Minas, em 1822), o cientista Vicente Coelho de Seabra Silva Teles, "Tente de zoologia, mineralogia, botânica e agricultura" da Universidade de Coimbra e autor do primeiro tratado de química publicado em língua portuguêsa (28), e o Pe. José Joaquim Viegas de Menezes, instalador da primeira tipografia que houve em Minas. O.que surpreende e vale como advertência a certas correntes dos nossos dias, que não acreditam poderem as humanidades levarem ao gôsto das ciências aplicadas, é êsse fato, comprovado à saciedade na segunda metade do século XVIII, de as escolas de latinidade de Minas Gerais prepararem e conduzirem tantos jovens promissores aos cursos científicos da reformada Universidade de Coimbra, a partir de 1772. Eis uma rápida lista dos cientistas formados ou homenageados na Europa, idos das aulas de latinidade de Minas e de outras Capitanias do Brasil: Frei José Mariano da Conceição Veloso; Alexandre Rodrigues Ferereira, Joaquim Veloso de Miranda, Manuel de Arruda Câmara, naturalistas; José Álvares Maciel e Vicente Coelho de Seabra Silva Teles, químicos; Domingos Vidal de Barbosa, José Joaquim da Maia, Francisco de Melo Franco, Manuel Joaquim Marreiros, medicina; José Vieira Couto, Manuel Ferreira da Câmara de Bittencourt e Sá, José Bonifácio de Andrada e Silva, José de Sá de Bittencourt e Acióli, mineralogistas; José Joaquim Viegas de Menezes, Manuel Rodrigues da Costa, José Gregório de Morais Navarro, politécnicos, magistrados e agronomistas. Todos filhos de escolas, régias ou eclesiásticas (modelos estas do que seria o primitivo Colégio do Caraça) dos fins da éra colonial.

Mas, já nos seus primeiros anos, o Caraça granjeia os seus inimigos. Num inquérito promovido pelo Corregedor da Comarca de Sabará, em 1823, depoentes atestam contra a casa, veiculando a acusação de que, em vez de estudos, ela dá reza, silêncio e má comida (29). Principalmente o cadete Antônio Teixeira de Miranda, ex-seminarista da casa, afirmando

\footnotetext{
"que só se destinão para o estudo 4 horas do dia, sendo o mais tempo aplicado à oração, recreio e silêncio";
}

a acusação evoca o vêzo contemporâneo do estudo sob a vista e a férula dos pedagosos rezinguentos do tempo, estudo feito em voz alta

(28). - Elementos de Quimica - eis o nome dessa obra pioneira, "tratado completo de quimica escrito em português, na coutrina anti-flogística", na expressão do especialista português Perelra Salgado (in "Histórla Monumental de Portugal", sob a direçåo de Damláo Peres, Barcelos (Portugal), Portucalense Editôra, 1934, 8 vols., t. VI, p. 530). Silva Teles foi discípulo de Lavolsier, em Paris.

(29) . - In R, A. P. M., Ano VI, p. 534 e 535. 
e cantada, para os mestres-escola ouvirem... Se, na verdade - como depõe outra testemunha - os jovens

"voitão dali mais estúpidos do que quando para ali entrão",

deveriam ser uns "caxias" excepcionais os alunos Manuel Joaquim de Oliveira Cardoso, Manuel Jacinto Rodrigues Braga e Higino Ferreira Paulino, porque defenderam, em 1828, teses públicas de Lógica e Metafísica, em latim, talvez as primeiras realizadas em Minas Gerais. Esses "artianos" (estudantes de filosofia) - in Imperiali Seminario ejusdem Facultatis auditores, isto é, auditores ou monitores do curso de filosofia no Imperial Seminário do Caraça - prepararam seu trabalhos e fizeram a disputatio em latim, sob a direção do Prof. Joaquim Antão Fernandes Leão (que viria a fazer uma bela carreira de homem público, no Segundo Império). Foi uma solenidade esplêndida (in hora solemni), realizada no recinto da capela de Nossa Senhora Mãe dos Homens, no dia 20 de julho de 1828, perante numeroso público, especialmente convidado (30), constituindo-se no ato final de encerramento do ano letivo. No Prooemium do folheto-convite da solenidade —cujo título é Theses Philosophicae de Logica et Metaphisica — vazado em latim até razoável, sente-se uma aura iluminista, quase kantiana, nesta passagem: Anima nostra, naturali felicitatis desiderio, quo pollet, se quasi invita in veritatis inquisitionem vergit, et nos nunquam medium aptius reperiri nullo negotio videmus, quam cognoscendi facultatem excolere, cum per Logicam, tum per Metaphisicam (31). Se a generosa alma dos jovens auditores caracenses é levada à investigação da verdade, pelo desejo natural da felicidade, êles não irão achar nenhum outro meio mais eficaz para isso, e para tôdas as outras coisas, do que cultivarem a faculdade do conhecimento, seja pelos caminhos exatos da Lógica, seja pelos da ciência metafísica, já que qualquer futuro estudo da suprema Teologia, sua meta final, e, mesmo, da Filosofia Moral, tanto em voga na época, haveria de requerer o domínio das regras claras da arte logística. Sôbre êsses pressupostos formacionais é que se assentará tôda a obra educativa do Caraça, em relação aos seus escolásticos que se destinam ao sacerdócio e aos próprios colegiais leigos que começam a encaminhar-se para as primeiras Academias de Direito (São Paulo e Olinda), que estão sendo fundadas. Essa filosofia curricular abrirá, consequientemente, os horizontes para

\footnotetext{
(30). - Conforme Folheto-convite, Impresso sob o título: Theses Philosophicae de Logica, et Metaphisica, Ouro Prêto, In Typographia de silva, 1828, que temos em máo.

(31). - Theses Philosophicae, cit., Prooemium.
} 
uma cosmo-visão harmoniosa da vida, preparando a elaboração de uma mentalidade clássico-humanista e cristã no espírito e no coração dos jovens caracenses, que passará a ser, desde então, a sua marca inconfundível, durante as gerações que ali se sucederem nos próximos cem anos.

Mas, a base e o veículo dessa formação humanística será a latinidade, como um uniforme cotidiano da vida escolar, mas também o grau togalício dos grandes certames intelectuais, a que vêm assistir até os imperadores brasileiros, em 1831 e em 1881 (32). E, contudo, como vimos pelo programa, não há nada de extraordinário nas aulas caracenses:

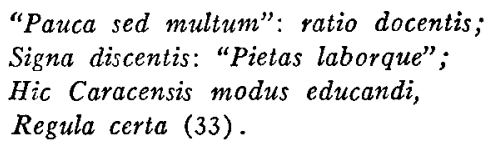

Eis a explicação, em rápidas palavras, que dá o Pe. Pedro Sarneel, C. M., em seus bem escandidos versos, aos métodos peda. gógicos do Caraça: "Pouco, mas bastante", eis o programa do professor, enquanto o lema do aluno é "piedade e trabalho": êste é o modo caracense de educar, esta é a norma certa. "Entretanto, êsse pouco de tudo não desdenhará, no que tange ao latim, uma boa aplicação aos melhores textos clássicos, principalmente "aos poetas, sendo necessário manusear o Gradus ad Parnasum, conhecer a metrificação, definir as figuras, analisar as qualidades", já que - segundo a afirmação do historiador Diogo de Vasconcelos, sôbre os cursos de latim da segunda metade do século do ouro das Minas Gerais,

$$
\begin{aligned}
& \text { - "nenhum estudante saía das aulas, que se não desse a com- } \\
& \text { posições" (34). }
\end{aligned}
$$

Talvez o primeiro poeta saído do Caraça seria aquêle anônimo autor de alguns hexâmetros dactílicos, guardados no Arquivo do $\mathrm{Ca}-$ raça, levando a data de 1828 . Não se sabe, ao certo, o autor. Há, ao lado dos versos, uma nota, com uma pergunta sôbre se seria o Pe. Manuel Joaquim Ferreira, o popular Pe. Ferreirinha. Mas, dúvida não há de que seu autor foi, com certeza, discípulo do Pe. João Moreira Garcez, lente da latim desde 1823. Oautor, que verseja

(32). - Com efelto, os imperadores D. Pedro I e D. Pedro II estiveram ambos no Caraça, respectivamente em 1831 e 1881, assistinclo ambos a debates escolares, oferecidos pelos estudantes da casa.

(33). - Pe. Pedro Sarneel, C. M., Dulcia Vitae Caracensis Gaudia, Belo Horlzonte, A. E. A. L. A. C., 1947, p. 9.

(34). - História Média de Minas Gerais, Belo Horlzonte, Imprensa Oficlal, 1918, p. 286 . 
muito bem, no que toca ao número de pés, mas desleixa um poucochinho a quantidade, invoca as musas literárias para cantar, em versos cheios de alegria, ao que parece, a terra brasileira, que é esta "a que nasceu sob os soberbos e vastos céus, reclinada que se acha no leito dos seus magnificos vergéis":

\section{Thespiades sacrae, laetos cantusque movete; Musa, precor, tristis, carmine, abesse meo. \\ Sed tu, Calliope dulcis, deducere cantus \\ Dic mihi festivos, blandisonosque, peto. \\ Ut possim modulari illam, quae nata superbis \\ In tectis vastis, magnificisque toris (35).}

Todavia, não há negar que, nesse longo curso de humanidades, que no Caraça duravam sete anos, o estudo do latim não era brincadeira. O venerando filólogo Pe. Antônio da Cruz, C. M., em seu livro $O$ Centenário do Caraça (36), é de opinião que havia, nos idos do primitivo Colégio, "quase um excesso" no ensino da latinidade. E, depois, se os Pes. Viçoso e Garcez - aquêle disciplinário e êste mestre de gramática latina - eram suaves e compreensivos, pessoalmente falando, nem por isso o regime disciplinar era de facilitar. Para mal dos pecados, filho da terra nova, provindo de uma sociedade em formação, fruto de uma aculturação doméstica ainda na fase crítica, o estudante brasileiro não se adaptava bem aos processos de um rigorismo natural na escola, clima comum daqueles homens severos e. disciplinados, que eram os lazaristas portuguêses. Os meninos não se davam muito bem, pois, com a disciplina, incorrendo em faltas freqüentes. Ora, as faltas escolares logo desencadeavam o funcionamento da pronta máquina disciplinar coercitiva da casa. Em sua clássica Vida de D. Antônio Ferreira Viçoso, D. Silvério Gomes Pimenta recorda que seu biografado

"não poupava a correção corporal nos casos em que a tinha por indisp:nsável" (37).

$\mathrm{E}$, as mais das vêzes, correção corporal queria dizer palmatória. Ah, a terrível "Santa Luzia" dos cinco olhos e seus devotos servidores, no Caraça! Os mestres e regentes do Colégio, partidários da filosofia corretiva (que ainda hoje os pedagogos britânicos defendem com tanta ênfase, repetindo os velhos conselhos do Dr. Johnson), faziam a apologia rasgada dos castigos corporais para educandos e

(35). - Arquivo do Caraça, C. A, no 14.

(36). - o Centenário do Caraça, Rio de Janeiro, Tip. Besnard Frères, 1920, p. 46.

(37). - D. Silverio Gomes Pimerta, Vida de $D$. Antônio Ferreira Viçoso, $2 a$. ediçāo, Mariana, Editôra da Arquidiocese, 1920, p. 32. 
não regateavam o uso da palmatória, da vara de marmelo, dos castigos e das cópias. Talvez não chegassem àquela minuciosa hermenêutica sôbre as ocasióes em que a férula deveria funcionar $\mathrm{cm}$ classe, elaborada catedràticamente pelo mestre-escola Jacob Lopes de Almeida, para os seus alunos da escola portguêsa de Guardão, em 1826 (38), mas sua eficiência no manejo da "Santa Luzia" era notável. Naqueles tempos, não se chegara ainda à fase mais evoluída da disciplina preventiva. Só a repressiva é que valia. Vinha a pêlo amiúde a advertência da Sagrada Escritura, que os mais velhos repetiam aos mais pequenos: Qui parcit virgae, odit filium (39). E vinha dos séculos passados um anexim antiguíssimo - "a letra entra com sangue" - que merecera as sátiras de Erasmo de Roterdão contra os excessos do castigo físico, que soferara no Colégio de Montaigu. Que o assunto sempre é motivo de interêsse, basta recordar que, ainda naqueles anos, para sermos exatos em 1827, viera êle à baila, na Assembléia Nacional do Império. O Sr. Batista Ferreira propusera a abolição dos castigos físicos, sob pena de culpa; mas, o Sr. Holanda Cavalcanti, que deveria ter aprendido, por experiência própria, os méritos pedagógicos da palmatória, replicara:

- "Quem quiser ensinar sem palmatória, que ensine; presumo, porém, que entre nós, atualmente haverá muito pouca gente capaz de ensinar sem palmatória".

E a lei de 15 de outubro daquele ano - a primeira que se fêz no país sôbre a instrução popular - manteve os castigos, que "serão os praticados pelo método de Lencastre" (40) ...

Os regentes, especialmente, serão os campeões das palmatoadas. São, geralmente, sujeitos de maus bofes (hoje os chamaríamos "complexados"). O ex-caracense Artur de Oliveira - que mais tarde, por um golpe de destino, seria o introdutor do parnasianismo no Brasil (41) - tem palavras amargas para êles, em suas cartas escritas do Caraça, em 1868 e 1869 (42). Serão, desde 1861, padres seculares, contratados de fora para o antipático mister. De palmatória em punho, andam "de aula em aula, de salão em salão, de re-

\footnotetext{
(38) . - Luís Albuquerque, Notas para a História do Ensino em Portugal, Coimbra, Edıçāo do Autor, 1960, 10 vol., p. 267-274.

(39) . - Livro dos Provérbios, Cap. XIII, vers. 24

(40). - Colleção das Leis do Imperio do:Brazil de 1827 (Parte Primeira), Rto de Janeiro, Typ. Nacional, 1878, p. 73.

(41). - V. trabalho nosso Artur de Oliveira e o Caraça, in Suplemento Literario do Estado de São Paulo, do dia 19 de dezembro de 1960.

(42). - In Dispersos, Rio de Janeiro, Civilizaçăo Brasilelra (Publicaç6es da Academia). 1936, (da p. 39 a 103), p. 83.
} 
creio em recreio, a todos nivelando com o seu avassalador domínio: cópias, cubículos, privações de recreio, reclusão e bolos eram

"o pão nosso de cada dia dessa geração de estudantes que por aqui passou"

- desabafa-se, com raiva, o antigo aluno Augusto da Costa Leite, em seu livro Saudades e Lembranças do Caraça (43). A lembrança dos tempos mais amenos dos Pes. Viçoso e Garcez - que os muitos decênios passados vão esfumando - acaba sendo suplantada, depois de 1860 , pela sádica atitude dêsses verdadeiros carcereiros da disciplina mal compreendida.

"Um dêles é o Pe. Antunes, que - segundo o ilustre historiador e homem de letras do Caraça, Pe. Francisco Silva, que acabou sendo promovido a Bispo do Maranhão, em princípios dêste século - amarrava o lenço no braço, para ter mais fôrça de puxar a palmatória" (44).

\section{E continua, um pouco mais adiante:}

"Havia tal lente da latim (lente da Artinha), que assim se chamava a primeira aula de latim, por causa da gramática do Pe. Antônio Pereira, que tinha êsse nome, por ser um resumo de sua grande obra: livreco que foi o compêndio por tantos anos, iniciador de gerações, na língua do Latim; havia tal lente qua se fazia garbo e timbre de não passar aluno algum por sua aula sem como se dizia na gíria colegial de então: "sem fazê-lo beijar a Santa Luzia". E era com verdadeira pachorra que às vêzes executava quase tôda a aula, sompre a mais numerosa, porque o latim era obrigatório e não podiam freqüentar outro curso sem primeiro passar por aquêle terrível promontório. Dizem que puxava a gaveta da mesa, tirava com tôda a delicadeza e carinho o fatal instrumento, colocava-o sôbre a mesa, tirava depois do bôlso o sangüineo lenço $d$ z alcobaça, espalmava-o nas mãos, assoava-se, dobrava-o e restituía-o ao bôlso da batina, de onde extraía agora a enorme e amarela caixa de pó. Abria-a e mergulhava o polegar e o índice da esquerda no sutil narcótico, com a graça de um tabaquista de raça. Tudo isso se passava, num silêncio que gelava de susto. Ouvia-se a respiração ofegante de alguns, e por vêzes o palpitar opressivo e precipitado do coração dos mais tímidos. Ia haver execução, muitos tinham sido interrogados, quais os que seriam castigados? Ninguem podia adivinhar no semblante do lente, não tinham visto nem um sinal que the alterasse a calma. Era sempre o mesmo, frio como o mármore. A pitada bem acalcada entre os dois dedos, acenava com a mão, para

(43). - Saudades e Lembranças do Carą̧a, São Paulo, E. G. Revista dos Tribunais, 1941, p. 187.

(44). - Contos Caracenses, in R. A. P. M., Ano XII, p. 250. 
cs pobres condenados ao suplício, que vinham se aproximando un atrás do outro como rebanho de carneiros para o matadouro. Sorvia a enorme pitada de pó e começava a execução" (45) ...

Esta descrição do autor dos Contos Caracenses focaliza um dos poucos "heróis" de triste figura que passaram pelo Caraça - o Pe. João Batista Fraissat - que fizeram da exceção uma lamentável regra geral, que iria dar ao Colégio a injusta fama com que amargou, por todo o fim do século passado e nos inícios dêste (46). Na verdade, o romancista e educador Bernardo Guimarães, que trabalhou com os Lazaristas em Congonhas do Campo, não presenciou violências com os alunos daquela casa do Senhor Bom Jesus de Matosinhos. O herói do romance $O$ Seminarista - Eugênio - é um “apos-

(45). - Ibidem. D. Silva - que assina essa parte de sua historiografia caracense "Histórias da Idade Média" com o pseudônimo de Fra Nigra - conclul o quadro afirmando que a "execução" "não devia ser terrível, porque o bom lente não era mau, era um hábito de longos anos que tomava no ensino, como o hábito do pó que era seu único vicio"... (p. 251).

(46) . - V. Gilberto Freyre, Sobraáos e Mucambos, São Paulo, Companhia Eđitôra Nacional (Brasiliana), 1936, 1a. edição, p. 56. O curioso é que o Pe. Joáo Batista Fraissat, o mais conhecido dos "cabeças-quentes" da palmatória (D. Francisco Silva) era um padre piedoso, que delxou boa lezibra zça no Caraça. Sôbre êle o Pe. Antônio da Cruz, C. M., sóbrio historiacior da institułçáo, exarou os seguintes conceltos: "Entre as almas caridosas, que forneceram recursos pecuniários para a construçāo do templo: a 1greja gótica atual, que o Pe. Júlio J. Clavelin fêz edificar, depois de demolir a capela do Irmão Lourenço, de tão belas tradiçōes, até artísticas, pois fôra pintada e decorada por Manuel da Costa Ataíde, como já divu'gamos, em nosso livro As Minas Gerais e os Primordios do Caraça, Sáo Pau1o, Companhia Editôra Nacional (Brasiliana), 1963, p. 326-330], sallentou-se a do Pe. Joāo Batista Fraissat, piedoso e santo sacerdote, do clero secular, que sempre viveu à sombra do Santuário do Caraça. Do seu pequeno ordenado de lente achava meio de tirar, todos os anos, alguma coisa para a igreja. Nas férias, bem longe de descançar, saía em viagem a esmolar, em animais proprios, com camarada pago por sua conta. Nada menos de vinte e dois contos angariou o Pe. Fraissat. Durante o ano, tinha organizada uma rifa perpétua e nem um so aluno, um só visitante lograva esquivar-se de comprar bilhete. Sua grande ambiçäo era morrer aqui e ser enterrado na cripta, onde já havia escolhido uma sepultura. Deus, porém, assim não quis. Finou-se no sul de Minas, em 1899". (O Centenário do Caraça, cit., p. 54-5). Grifamos no texto citado aquêles trechos que se nos figuram elucidativos do caráter dêsse estranho sacerdote. Primeiro, êle nos parece um egresso da vida do vigário secular, fracassado em sua vocação de pastor de almas, motivo por que se fol refugiar numa casa regular, quase monástica. Segundo, deveria ser obsessivo e sistemático, com certeza um misantropo, aferrado a principios e hábitos jamais imudados, mesmo que isso lhe custasse sacrifícios e privaçóes de tôda a ordem. Solitário, terrivelmente solitárlo, êsse homem, sem votos religiosos, náo tinha para onde ir. Sem afeiçóes humanas, mas também sem afeiçóes espirituais, telmoso, telmosissimo, no seu tabaco, na sua "santa-luzia", nas suas viagens anuais por conta própria, na sua rifa perpétua, na sua venda a todos e a cada um em particular, na sua visita talvez diáría à sepultura que o Iria cobrir um dia... Só Deus - coitado dêsse padre obsedado! - podería escapar da sua rifa... ou da sua "santa-luzia!" 
tólico" da Congregação da Missão ali, o qual, como sabemos, acaba se ordenando. $O$ jovem frequienta as lições de gramática latina e as acha "fastidiosas":

"o compêndio de Antônio Pereira foi para êle um pesadelo". "Lia e relia as páginas da lição a ponto de as esfarelar para conseguir gravar na memória algumas palavras" (47).

E' que o moço estava apaixonado pela sua Margarida e não punha gôsto em nada. Mas, um pouco adiante, o romancista apresenta um quadro diferente:

\footnotetext{
"Eugênio já tinha entrado para a t:rceira classe de latim e, começando a traduzir Os Tristes de Ovídio e as Eclogas de Vergílio, sentiu-se tomado de um vivo gôsto pela poesia. (...) Vergílio, de um lado, e Ovídio, do outro, deram-lhe as mãos e o introduziram no templo da harmonia. (...) Eugênio, pois, ao ler os primeiros versos de Vergílio, sentiu na fronte o bafejo do anjo da poesia que lhe dava à alma como um sentido mais, abrindo nela uma fonte nova de suaves e inefáveis emoçōes" (48).
}

Um estudante que se sentia assim não haveria de estar contìnuamente sob a mira dos cinco olhos de sucupira de alguma "Santa Luzia" implacável... Por outro lado, o seminarista Eugênio vive num ambiente bem diferente daquele em que o Visconde de Taunay vai colocar, preconceituosamente, o herói da Inocência, o moço Cirino, que é recolhido ao Caraça,
"no internato em que devia passar tristonhamente os melhores anos de sua adolescência, a mastigar latim, gaguejar Telêmaco e entoar dia e noite e em falsete uns trechos de canto-chão" (49)...

No superiorato do Pe. Júlio José Clavelin, que vai de 1867 a 1885, o Colégio do Caraça conhece o seu maior esplendor. Pertence a êsse período áureo o avultado número de cartas que dali o aluno gaúcho Artur de Oliveira escreve aos seus. Essas cartas fazem muita luz sôbre o regime escolar dêsse tempo. O jovem estudante manifesta, desde o primeiro momento de sua chegada, um grande entusiasmo pelos Lazaristas, que chama de "poços de ciência" (50). Reporta-se a lingüistas que sabem até dez línguas muito bem (51); um dêles, o Pe. Gonçalves, escrevera a história do Brasil em versos

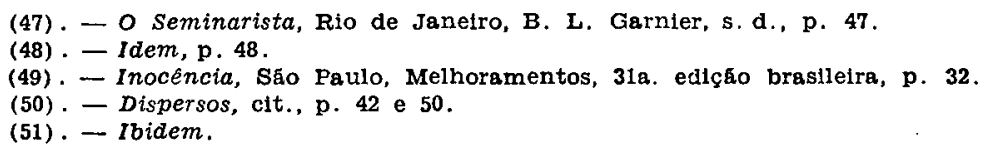


latinos (52). Artur afirma estudar latim, "porque aqui se ensina perfeitamente" (53), tendo duas aulas por dia; parece entusiasmar-se pela matéria, porque se habitua a encaixar, nas suas cartas, frases latinas a que acrescenta sua contribuição principiante (54). O moço riograndense diz que não

\begin{abstract}
"estuda matemáticas porque essas aulas são no mesmo dia das de latim e por isso não as pode freqüentar, porque freqüenta as de latim, que é muito necessário e útil, para o seu futuro, e para se matricular" [na Faculdade de Direito] (55).
\end{abstract}

Conta ainda que fêz amizade com o Pe. Sena Freitas, que então estagia por três anos no Caraça (56). Parece, porém, que se é verdade o que conta o jovem missivista sôbre o ambiente e as pessoas, é menos exato o que alardeia sôbre o seu aproveitamento nos estudos. Fomos ver-lhe a situação escolar, no Livro de Notas, correspondente aos anos de 1868-1869, e lá atinamos, a fls. 26-v, o seguinte resultado: "Artur de Oliveira — Latim, 3; Português e Retórica, 4; Francês, 4; Inglês, 3 - Comportamento, 2. E mais esta anotação, no canto da fôlha, na coluna das "Observações": "Pouco juízo". Uma das poucas provas de juízo que Artur demonstra ter, em sua passagem pelo Caraça é o amor à Biblioteca da casa:

"O viver da cabeça, meu pai - escreve êle ao progenitor - é que paga o sofrer, pois que verdadeiramente aqui é um foco de letras: basta ter a casa a Biblioteca que tem". "Fiquei pasmo - continua no mesmo tom - quando entrei na Biblioteca, há livros no Caraça que talvez não exista segundo exemplar no Brasil. O distinto Pe. Sipolis excavou tôdas as bibliotecas em Portugal e comprou livros, a que a Academia Real de Ciências oferecia um preço fabuloso. Ele é um grande helenista português" (57).

O Pe. Miguel Maria Sipolis, ex-Superior, era um grande helenista, mas francês. Pertencia ao grupo notável de filhos de São Vicente de Paulo, vindos de França para o Caraça, logo após a chegada das primeiras Irmãs de Caridade, que a chamado de D. Pedro

(52). - Ibidem. Esse Pe. Gonçalves seria, mais provàvelmente, o Pe. Antônio Valeriano Gonçalves de Andrade, natural de Pitangui, e entrado, com vocação tardia, no Caraça, em 1824, aos 30 anos de idade, e que, em 1828, data dos versos acima lembrados, parecia já estar ordenado. Brasileiro, homem de mérito e cultura, Superior em Congonhas, permanecendo por vinte anos no Caraça, onde faleceu em 17 de fevereiro de 1869, teria sido mestre de Artur de Oliveira.

(53). - Idem, ibidem.

(54). - Op. cit., p. 69.

(55). - Idem, p. 67.

(56). - Idem, p. 55.

(57). - Idem, p. 42 e 45. 
II, vieram incumbir-se da Santa Casa de Misericórdia do Rio de Janeiro, logo nos primeiros anos da segunda metade do século passado. Com efeito, em viagem que fizera à Europa, o Pe. Miguel $\mathbf{M}$. Sipolis trouxera de lá uma grande quantidade de-livros preciosos, principalmente obras latinas editadas antes de 1600, que fazem sempre o encanto de um humanista que se preze. São cento e quatro volumes, todos ricamente encadernados, de oitenta mil páginas, muitas delas impressas antes ou durante os anos em que se descobria o Brasil (58). Livros êsses que subiram a Serra, na década 1860-1870, penosa mas carinhosamente, em lombo de burro, como canta graciosamente a grande poetisa mineira Henriqueta Lisboa:

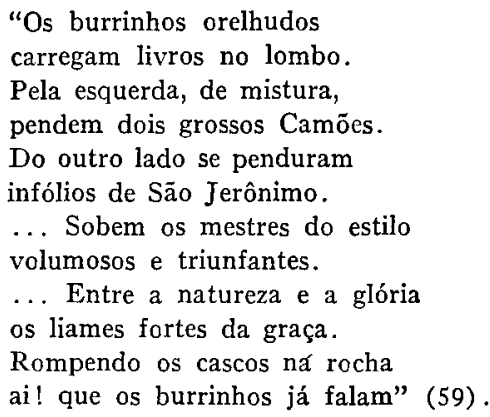

Muitos dêsses livros fizeram tão longa viagem, até aquêle alteroso sertão, porque o erudito $\mathrm{Pe}$. Sipolis, mestre e guia de homens como Afonso Pena, Artur de Oliveira, Olegário Maciel, João Ribeiro, Artur Bernardes, Arduíno Bolivar, Afonso Pena Júnior, Melo Viana e Manfredo Leite, entre tantos outros, quis formá-los bem para a vida e a beleza, mediante o amor e a prática da cultura humanística latina, guardada nobremente naqueles cimélios respeitáveis, que se aprazia em colocar nas mãos adolescentes dos jovens alunos caracenses, que viriam depois dignificar tão alto o espírito com que foram formados e informados, elevando-se acima dos comuns e elevando, com êles, o Brasil e os brasileiros.

\footnotetext{
(58). - A Biblioteca do Caraça foi das mals ricas. Em exposição promovida sob os auspícios da sucursal de "O Glôbo", em Belo Horizonte, em setembro de 1960, apresentou quarenta e sete exemplares quinhentistas, de Veneza, Roma, Lião, Paris, Antuérpia, Amsterdão, Salamanca, Alcalá de Hevares, Colônia e Lisboa, impressóes feitas por Simon de Colines, Froben, Gryphins, Estienne, Plantinus, Elzevir, Antônio e João Blado, Bevilacqua, Francisco Correia, etc., entre outras preciossidades. Infelizmente, essa Biblioteca, que se achava mal instalada em velho salão de uma das alas do edifício do Colégio, foi quase inteiramente destruída por incendio, em malo de 1968.

(59). - Montanha Viva, Belo Horizonte, Imprenssa Oficial, 1959, p. 75-76.
} 